\title{
Management of innovation processes at the enterprises of the construction materials industry
}

\author{
Nikolay Voytolovskiy ${ }^{1,}$, Ekaterina Maslyukova ${ }^{2}$, Margarita Aleksandrova ${ }^{2}$, Varvara \\ Dikareva $^{3}$, Alexander Fadeev ${ }^{4}$ \\ ${ }^{1}$ Sankt-Petersburg State Economic University, 21, Sadovaya street, St. Petersburg, 191023, Russia \\ ${ }^{2}$ Moscow state University of technology and management. K.G. Razumovsky, Zemlyanoy Val street, \\ 73, Moscow, 109004, Russia \\ ${ }^{3}$ Moscow State University of Civil Engineering, Yaroslavskoye shosse, 26, Moscow, 129337, Russia \\ ${ }^{4}$ Bauman Moscow State Technical University, 2nd Baumanskaya street, 5/ 1,105005, Moscow Russia
}

\begin{abstract}
The purpose of this paper is the development of a methodical approach to management of the parameters of the life cycle of innovations. This approach ensures the increase of the efficiency of economic activity by intensifying the processes of innovative development of industrial enterprises. As a result of the research, the features of the processes for implementing the life cycle of innovations were determined; the system of criteria for assessing the efficiency of management of the parameters of the life cycle of innovations was developed; a management model for the parameters of the life cycle of innovations was formed; and a management mechanism for the life cycle of innovations in a saturated market was developed.
\end{abstract}

\section{Introduction}

In the process of innovative development, domestic industrial enterprises face not only the problem of generating ideas for creating new processes and products that are competitive in the market, but also with the problems of introducing innovative ideas into the production process. The testing of new processes and products by industrial enterprises often involves the use of specialized testing and measuring equipment. On the one hand, this requires an assessment of the degree of adaptation of innovations being introduced from the perspective of existing standards which minimize the current costs through unification. On the other hand, the introduction of innovation processes and products often requires the revision of existing standards [1].

Therefore, each of the components of innovative development of industrial enterprises at the stage of testing, certification and standardization of innovation processes and products requires the adoption of compromise solutions related to the rationalization of the use of all types of resources. In this regard, the improvement of the management system of the parameters of the life cycle of innovations at the stage of testing, certification and

\footnotetext{
*Corresponding author: voytolovskiy@mail.ru
} 
standardization, taking into account the characteristics of the innovations themselves, strengths and weaknesses of the organization, market opportunities and external threats, is an important scientific task.

\section{Materials and methods}

Determined in the process of research, the main content of the innovation activity of industrial enterprises and the stages of its implementation are given in Table 1.

Therefore, testing, certification and standardization of new processes and products nominally accompany four of the twelve stages of innovation activity of industrial enterprises. It is reasonable to investigate the current trends in the innovative development of industrial enterprises for more accurate assessment of the impact of testing, certification and standardization of new processes and products on the innovative development of industrial enterprises [2].

Table 1. The main content of innovation activities of industrial enterprises and the stages of its implementation.

\begin{tabular}{|c|c|c|}
\hline № & Stage & Content \\
\hline 1 & $\begin{array}{l}\text { Analysis of } \\
\text { market needs and } \\
\text { potential } \\
\text { opportunities of } \\
\text { the industrial } \\
\text { enterprise }\end{array}$ & $\begin{array}{l}\text { - analysis of the general state of the serviced market, its structure } \\
\text { and needs in separate areas; } \\
\text { - place of the enterprise in the market, the volume of product } \\
\text { sales, quality, price; } \\
\text { - actions of direct and potential competitors; } \\
\text { - economic situation of the enterprise, its financial condition; } \\
\text { - availability for insuring the risks of innovation activity }\end{array}$ \\
\hline 2 & $\begin{array}{l}\text { Formation of } \\
\text { innovation policy }\end{array}$ & $\begin{array}{l}\text { - selection of the long-term goals on the basis of an analysis of } \\
\text { options for the possible development of innovation activities; } \\
\text {-formation of program directions for the development of } \\
\text { innovation activities }\end{array}$ \\
\hline 3 & $\begin{array}{l}\text { Planning } \\
\text { innovation } \\
\text { activity }\end{array}$ & $\begin{array}{l}\text { - Strategic planning of innovation activity of the enterprise; } \\
\text { - Operational planning for the implementation of innovation } \\
\text { activity }\end{array}$ \\
\hline 4 & $\begin{array}{l}\text { Organization of } \\
\text { innovation } \\
\text { activity }\end{array}$ & $\begin{array}{l}\text { Formation of the innovative subsystem and innovative } \\
\text { infrastructure from the perspective of rational combination of } \\
\text { own, joint and acquired innovations }\end{array}$ \\
\hline 5 & $\begin{array}{l}\text { Approbation of } \\
\text { the scheme of } \\
\text { innovation } \\
\text { activity } \\
\text { implementation }\end{array}$ & $\begin{array}{l}\text { Launching of the innovative subsystem and the assessment of its } \\
\text { operation based on the results of the implementation of the first } \\
\text { innovation projects }\end{array}$ \\
\hline 6 & $\begin{array}{l}\text { Start of intensive } \\
\text { implementation } \\
\text { of innovation } \\
\text { activity }\end{array}$ & $\begin{array}{l}\text { After making adjustments to the innovative subsystem, based on } \\
\text { the results of approbation of operation, a full-scale } \\
\text { implementation of the innovation activity program begins }\end{array}$ \\
\hline 7 & $\begin{array}{l}\text { Obtaining of } \\
\text { scientifically } \\
\text { significant } \\
\text { theoretical results }\end{array}$ & $\begin{array}{l}\text { Patenting of rights to innovation products (methods of operation } \\
\text { and devices that implement them) }\end{array}$ \\
\hline 8 & $\begin{array}{l}\text { Modeling of } \\
\text { innovation } \\
\text { products }\end{array}$ & $\begin{array}{l}\text { Implementation of scientific research work with the physical } \\
\text { modeling of new products }\end{array}$ \\
\hline 9 & $\begin{array}{ll}\begin{array}{l}\text { Development } \\
\text { prototypes }\end{array} & \text { of } \\
\text { products } & \text { of } \\
\end{array}$ & $\begin{array}{l}\text { Implementation of development work with the manufacture of } \\
\text { pilot batches of products; testing, standardization and } \\
\text { certification of products; formation of regulatory documentation }\end{array}$ \\
\hline
\end{tabular}




\begin{tabular}{|c|l|l|}
\hline 10 & $\begin{array}{l}\text { Production of } \\
\text { pilot batches of } \\
\text { will be implemented. } \\
\text { innovation } \\
\text { products }\end{array}$ & $\begin{array}{l}\text { The beginning of batch development of products, accompanied } \\
\text { by the development of production technology, studying the } \\
\text { reaction of consumers to the proposed products and the } \\
\text { corresponding adjustments to the regulatory documentation. }\end{array}$ \\
\hline 11 & $\begin{array}{l}\text { Beginning of } \\
\text { batch production } \\
\text { of innovation } \\
\text { products }\end{array}$ & $\begin{array}{l}\text { The launch of batch production of innovation products, } \\
\text { accompanied by the increase in production volumes and the } \\
\text { emergence of profits from its implementation. At the same time, } \\
\text { standardization of proven production processes is carried out. }\end{array}$ \\
\hline 12 & $\begin{array}{l}\text { Product } \\
\text { modernization }\end{array}$ & $\begin{array}{l}\text { The slowdown in the growth of production volumes and sales of } \\
\text { products, caused by its moral aging, increasing competition and } \\
\text { "satiation" of the market with the proposed products, which } \\
\text { requires product modernization }\end{array}$ \\
\hline
\end{tabular}

Based on the research of problems of managing the parameters of the life cycle of innovations in work, an algorithm for their solution is formed and presented in Fig. 1.

The proposed algorithm allows analyzing the features of managing the parameters of the life cycle of innovations and improving the management processes for the parameters of the life cycle of innovations [3].

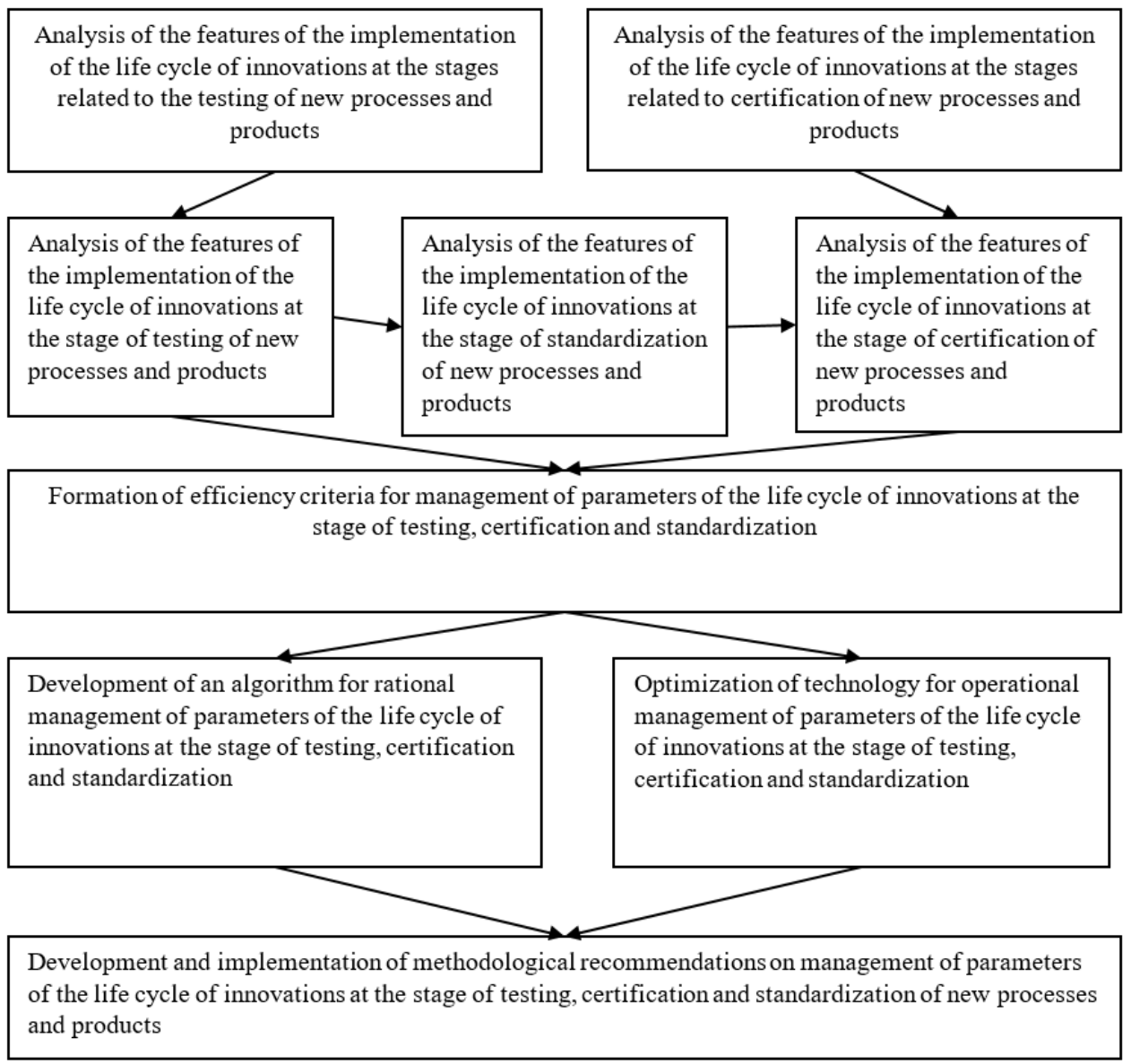

Fig. 2. Development of an algorithm for solving the problems of managing the parameters of the life cycle of innovations. 
Within the scope of research, control and market tests, the features of testing the products which have radical innovations are to determine the opportunities for the manufacturer to obtain new functional properties of products through the prism of the reaction of buyers to the offer of qualitatively new consumer properties. Therefore, this means testing of the created basic properties of innovation products. Within the scope of control, market and comparative tests, the features of testing the products which have ameliorative innovations, are to determine the ratio of the increment of the effect obtained to the increment of the costs for its achievement [4].

\section{Results}

The results of the analysis of the features of standardization and certification of innovation processes and products in comparison with the standardization and certification of traditional processes and products are presented in Fig.2. Standardization and certification in the production of innovation products are the factors of:

- stimulation of the processes of innovation renewal of products,

- increase of the efficiency of production processes,

- increase of the efficiency of the criteria for the comparative assessment of production by the level of the standards used,

- development of technologies that ensure the reduce of production unit costs.

It should be noted that the features of standardization and certification of innovation processes and products presented in Fig. 4 are indicative for all types of innovations radical, ameliorative and rationalizing. Based on the analysis of the features of managing the parameters of the life cycle of innovations in work, criteria for assessing the efficiency of managing the parameters of the life cycle of innovations at the stage of testing, certification and standardization were formed [5].

Criteria for assessing the efficiency of managing the parameters of the life cycle of innovations at the stage of testing are the system $\mathrm{R}_{\text {TEST }}$ that represents the efficiency of all specific tests, assessed on the basis of the equation:

$$
\mathrm{R}_{\mathrm{TEST}}=\frac{\sum_{i=1}^{m} \beta_{\mathrm{i}} \cdot \mathrm{R}_{\mathrm{i}}}{\sum_{i=1}^{m} \beta_{\mathrm{i}}}
$$

where $\mathrm{R}_{\mathrm{i}}$ - value of the $\mathrm{i}$-th group criterion of tests;

$\beta_{\mathrm{i}}-$ weight coefficient of the $\mathrm{i}$-th group criterion of tests;

$\mathrm{m}$ - number of group criteria for assessing the tests.

$\mathrm{R}_{\mathrm{i}}$ - group criteria for assessing the efficiency of managing the parameters of the life cycle of innovations

In these conditions, each of their group criteria for assessing the efficiency of managing the parameters of the life cycle of innovations at the stage of testing is determined on the basis of universal equation:

$$
R_{i}=\left(\left[I_{i}\right]^{\alpha_{i}} \cdot\left[N_{i}\right]^{\varepsilon_{i}} \cdot\left[T_{i}\right]^{\eta_{i}}\right) /\left[C_{i}\right]^{\mu_{i}},
$$

where $I_{i}$ - relative informativeness of the i-th type of tests,

$N_{i}$ - relative reliability of information of the i-th type of tests, 
$T_{i}$ - relative reduction of the time frame of the $\mathrm{i}$-th type of tests,

$C_{i}$ - relative increase in the cost of conduction of the i-th type of tests,

$\alpha_{i}, \varepsilon_{i}, \eta_{i}, \mu_{i}$ - weight coefficients of the criteria of informativeness, reliability, reduction of the time frame and increase in the cost of the i-th type of tests, determined from the condition $\alpha_{i}+\varepsilon_{i}+\eta_{i}+\mu_{i}=1$.

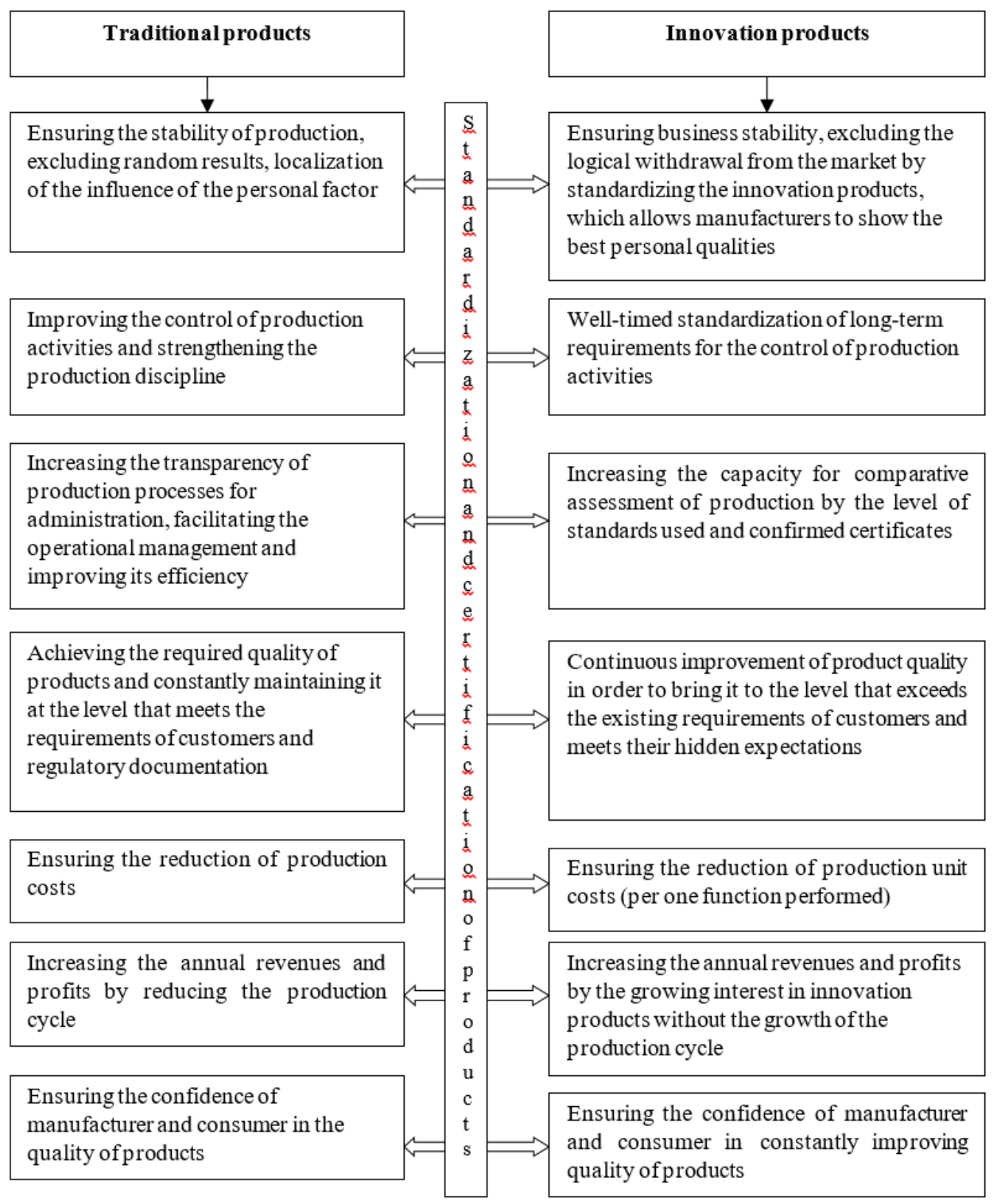

Fig. 2. Features of standardization and certification of innovation processes and products in comparison with traditional ones.

Criteria for assessing the efficiency of managing the parameters of the life cycle of innovations are the system $\mathrm{U}_{\mathrm{CC}}$ that represents the degree of achievement in the 
implementation of standardization and certification processes of planned results, assessed from the equation:

$$
\mathrm{U}_{\mathrm{SC}}=\frac{\sum_{j=1}^{n} \gamma_{\mathrm{j}} \cdot \mathrm{U}_{\mathrm{j}}}{\sum_{j=1}^{n} \gamma_{\mathrm{j}}}
$$

where $\mathrm{U}_{\mathrm{j}}$ - value of $\mathrm{i}$-th group criterion;

$\gamma_{j}$ - weight coefficient of $\mathrm{j}$-th group criterion of standardization and certification;

$\mathrm{n}$ - number of group criteria for assessing standardization and certification.

$U_{j}$ - group criteria for assessing the efficiency of innovation.

In these conditions, each of the group criteria for assessing the efficiency of managing the parameters of the life cycle of innovations is determined on the basis of universal equation:

$$
U_{j}=\left(\left[Q_{i}\right]^{\chi_{j}} \cdot\left[W_{j}\right]^{\varphi_{j}} \cdot\left[E_{j}\right]^{\kappa_{j}}\right) /\left[Y_{j}\right]^{\vartheta_{j}}
$$

where $Q_{j}$ - relative growth of functionality of innovation products in the implementation of the $\mathrm{j}$-th direction of standardization and certification,

$W_{j}$ - relative growth of the operational efficiency of innovation products in the implementation of the $\mathrm{j}$-th direction of standardization and certification,

$E_{j}$ - relative reduction of the production cycle for the creation of innovation products in the implementation of the $\mathrm{j}$-th direction of standardization and certification,

$Y_{i}$ - relative increase in the cost of implementation of the $\mathrm{j}$-th direction of standardization and certification,

$\chi_{j}, \varphi_{j}, \kappa_{j}, \vartheta_{j}$ - weight coefficients of the criteria of functionality, operational efficiency, reduction of the production cycle and increase in the cost of implementation of the $\mathrm{j}$-th direction of standardization and certification, determined from the condition $\chi_{j}+\varphi_{j}+\kappa_{j}+\vartheta_{j}=1$.

While improving the processes of management of the parameters of the life cycle of innovations at the stage of testing, certification and standardization of new processes and products, the management model for the parameters of the life cycle of innovations during testing, standardization and certification was formed at the first stage [6].

The proposed model (Fig. 3) changes the stereotype that testing, certification and standardization of new processes and products cover only one stage of the life cycle of innovations. 


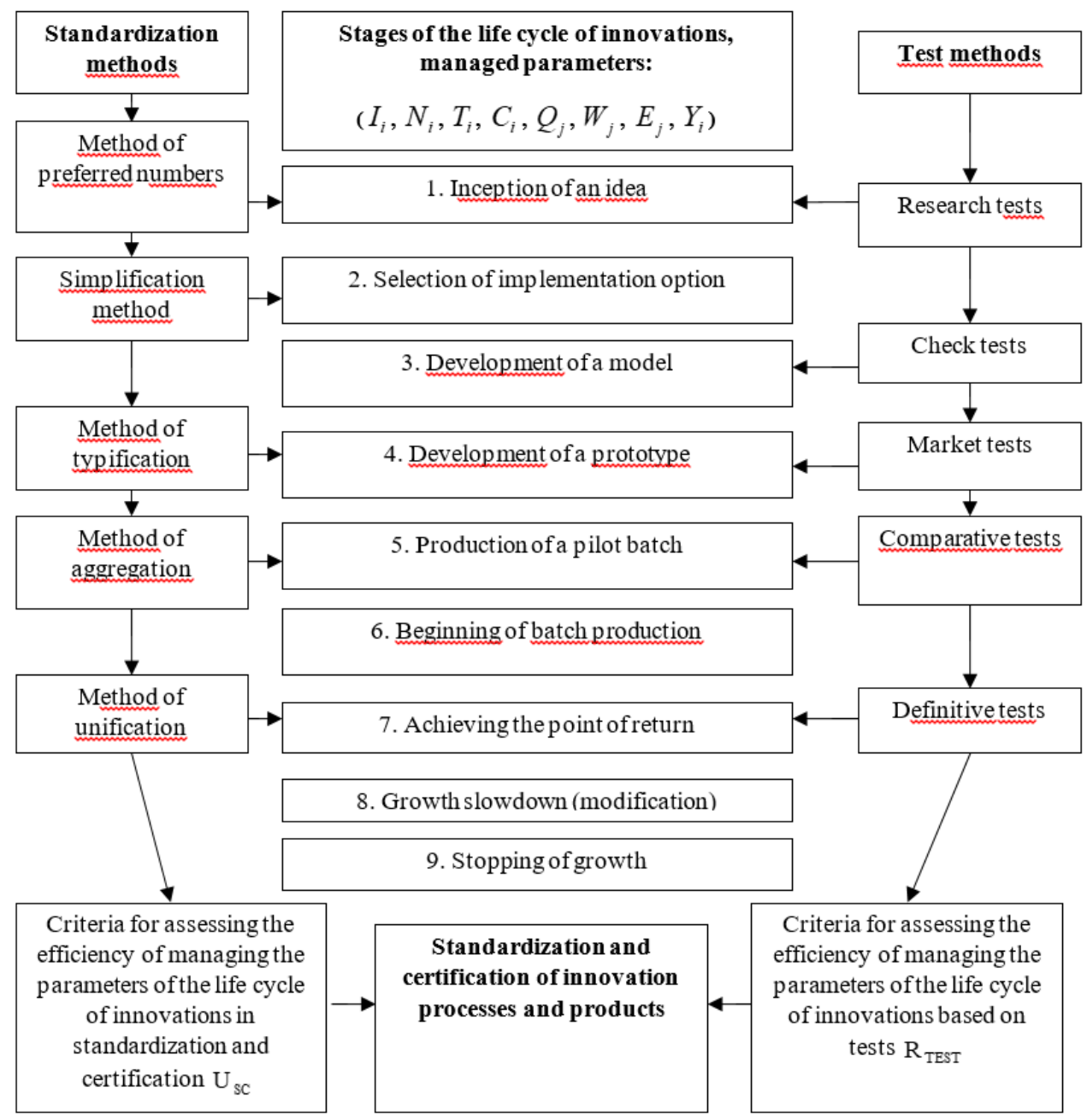

Fig. 3. Formation of the management model for the parameters of the life cycle of innovations

\section{Discussion}

The proposed mechanism provides for the implementation of the following management algorithm.

1. On the basis of tests, establishment of the required values of the criteria for assessing the efficiency of the life cycle of innovations.

2. Definition of the base indicators for assessment.

3. Determination of the weight coefficients of the criteria of informativeness, reliability, reduction of the time frame and increase in the cost of carrying out each type of tests.

4. Calculation of the actual values of the criteria for assessing the efficiency of managing the parameters of the life cycle of innovations and the criteria for assessing the efficiency of management of life-cycle parameters.

5. Comparison of the actual and basic values of the criteria for assessing the efficiency of managing the parameters of the life cycle of innovations.

6. In the case of a negative comparison of the actual and basic indicators, the procedure for step five is repeated. 


\section{Conclusion}

The implementation of the management mechanism for the parameters of the life cycle of innovations meets the conditions of the innovation market saturation and corresponds to the principle of constant increase in the efficiency of the enterprise. At the final stage of the research, methodological recommendations for managing the parameters of the life cycle of innovations in testing, certification and standardization of new processes and products of industrial enterprises were formed.

\section{References}

1. A. Larionov, E. Nezhnikova, International Journal of Applied Engineering Research 6, 4433-4439 (2016)

2. A. Jones, G. Fallon, R. Golov, European Business Review 12(4), doi:10.1108/09555340010336871

3. E. Nezhnikova, R. Obukhov, MATEC Web of Conferences 106, 08025 (2017) https://doi.org/10.1051/matecconf /201710608025

4. D.N. Silka, M.A. Ivanova, Vestnik MGSU 12-5(104), 572-580 (2017) doi: 10.22227/1997-0935.2017.5.572-58

5. V. Kankhva, D. Silka, Procedia Engineering 165, 1337-1342 (2016)

6. D.N. Silka, MATEC Web of Conferences, 07012 (2016) 